FILIP GOŁĘBIEWSKI

Instytut Socjologii UMK

\title{
Między totalitaryzmem a (jałowym) pluralizmem. O ładzie medialnym w III RP
}

„Na polanie w lesie zebrały się zwierzęta. Dość już tej wzajemnej niesprawiedliwej walki. Proponuje powszechne rozbrojenie. Trzeba ustalić jakieś zasady oświadczył nosorożec. - Od dzisiaj każdy może mieć jeden róg na nosie - skonkretyzował swoją propozycję"*

Drojekt polityczny, jakim była (jest?) III RP, zasadzał się na transformacji, czyli istotnym przekonfigurowaniu priorytetów i zasad funkcjonowania na co najmniej trzech polach: prawnym, instytucjonalnym i kulturowym. Owe pola nie funkcjonują, rzecz jasna, w oderwaniu od siebie. Są ze sobą wzajemnie sprzężone i powiązane. Zmiany na jednym z nich pociągają za sobą zmiany na drugim, jednocześnie wpływając na trzecie. Polem, na którym transformacja mogła dokonać się stosunkowo najszybciej było pole prawne, następnym w kolejności instytucjonalne, a najwolniej - ze względu na głębokość zakorzenienia kwestii z nim związanych wśród członków społeczeństwa - zmianom podlegało i podlega pole kulturowe. Właśnie zmianom na tym ostatnim warto przyjrzeć się nieco bliżej, gdyż wydaje się ono być najszerszym i stanowić swoisty „futerał” dla zmian na polach pozostałych.

P. Semka, „Gazeta” z palcem na cynglu, „Rzeczpospolita” z dn. 04 III 2009. 
Pole kulturowe rozumiem jako zbiór różnych, ale mających swój wspólny kręgosłup: postaw, wzorów zachowań, drogowskazów etycznych i moralnych oraz systemów norm i wartości (struktur aksjologicznych) wyznaczających ścieżki, którymi powinno podążać zagubione społeczeństwo. To na tym polu tworzą się (lub zostają rozproszone) takie zjawiska, jak: poczucie tożsamości i wspólnoty narodowej, pamięć historyczna, postawy obywatelskie, świadomość podmiotowości, chęć debaty na ważne dla dobra wspólnego tematy. Aby powyższe zjawiska mogły się wytworzyć w sposób realny potrzebny jest pośrednik, za pomocą którego jednostki mogłyby „zapośredniczać" doświadczenia będące poza ich zasięgiem, czerpać wiedzę o świecie i ludziach oraz „uwewnętrzniać” autorytety. Owym przekaźnikiem były niegdyś przede wszystkim różnego rodzaju instytucje społeczne (takie jak np. rodzina), jednak, jak pisze Denis McQuail, „pojawił się nowy, dodatkowy pośrednik (komunikowanie masowe), który może wzmacniać, zastępować albo niweczyć wysiłki innych instytucji społecznych, może też z nimi konkurować".

Ten nowy pośrednik ma jedną niepodważalną przewagę nad wcześniejszymi formami „zapośredniczania” doświadczenia: oferuje znacznie szersze horyzonty. Dzięki niemu jednostka w każdej chwili może czuć się obywatelem świata, mieć grono (wprawdzie wirtualnych, ale za to zawsze uśmiechniętych) przyjaciół, „spotykać się” z gwiazdami showbiznesu, podziwiać piękne, wysportowane ciała, i otrzymywać wiele innych wirtualnych lecz jawiących się jako realne - atrakcji. Wszystko to otrzymuje się natychmiast. Niemal bez żadnego wysiłku.

Mimo że rozważania na temat konsekwencji wynikających $\mathrm{z}$ powszechnego i, co ciekawe, niemal całkowicie niezauważalnego zagnieżdżenia się owego masowego pośrednika między jednostkami a rzeczywistością we współczesnych cywilizowanych społeczeństwach, wydają się pasjonujące, to jednak nie są one głównym przedmiotem niniejszego tekstu. Są nimi przedstawiciele owego „dodatkowego pośrednika”, czyli media, a w szczególności media masowe. To właśnie one, czy tego chcemy, czy nie, stanowią w dzisiejszych czasach podstawowe forum, swoistą scenę, na której dokonuje się transformacja, na wspomnianym wcześniej, polu kulturowym. Nie są wprawdzie jedynym miejscem, gdzie ta niezwykle istotna rekonfiguracja się dokonuje, ale zajmują wśród nich pozycję zdecydowanie dominującą. „,́rodki komunikowania (media) nie są tylko technicznymi urządzeniami do przenoszenia różnych treści, ale każdy z nich wywiera swoisty wpływ na orienta- 
cje intelektualne, sposoby opisywania rzeczywistości i wrażliwość ich użytkowników, na charakter publicznego dyskursu i całą kulturę"2.

Odnosi się to również do polskiej rzeczywistości (po)transformacyjnej. Założenie, które w tym miejscu należy przyjąć, jest takie: dla powodzenia transformacji na polu kulturowym III RP niezbędna była i jest powszechna debata w dyskursie publicznym, odbywająca się na zasadach pluralizmu, czyli „w poszanowaniu dla zróżnicowań społecznych i kulturowych, gwarantująca różnym grupom społecznym i politycznym prawo wyrażania swych interesów (politycznych, społecznych i ekonomicznych) oraz udział w sprawowaniu władzy”. Kategoria "pluralizmu” jest jedną z najważniejszych składowych systemu demokratycznego, którym miała się stać, w myśl projektu politycznego, III RP. Skoro tak, to ów pluralizm powinien objawiać się również w odniesieniu do mediów. Zdefiniujmy go zatem następująco:

„Oznacza (on) różnorodność oferty środków komunikowania masowego, rozmaitość programową, odnoszącą się do zróżnicowanych systemów wartości, zapewnienie wielostronnej politycznie informacji, a także zapobieganie tendencjom monopolistycznym. Współcześnie, m.in. w dokumentach Rady Europy dotyczących mediów, rozróżnia się pluralizm zewnętrzny i wewnętrzny. Pierwszy z nich oznacza p. instytucji medialnych, a drugi p. treści, odnoszący się do zróżnicowania poglądów, tematów, opinii, idei i stanowisk oraz ich reprezentacji politycznej i kulturowej w tej samej gazecie, czasopiśmie, a także kanale radia i telewizji”'.

Przy tak zdefiniowanym pojęciu centralnym niniejszej pracy można przejść do postawienia głównego pytania wywodu: czy w Polsce po 1989 roku mieliśmy do czynienia $\mathrm{z}$ dochowaniem, tak istotnej, zasady pluralizmu na rynku medialnym ${ }^{5}$ ?

2 N. Postman, Zabawić się na śmierć, Warszawa 2002, s. 6; fragment wstępu do wydania polskiego autorstwa Macieja Mrozowskiego.

3 Pluralizm, w: Stownik terminologii medialnej, red. W. Pisarek, Kraków 2006, s. 147-148.

4 Tamże; warto zwrócić uwagę na fakt, że w ustawie prawo prasowe z dn. 28 stycznia 1984 roku w art. 10 ust. 2 i 3 znajduje się zapis mówiący o obowiązku realizowania przez dziennikarza ustalonej linii redakcyjnej danej gazety. Stoi to w oczywistej sprzeczności z przytoczoną definicją pluralizmu wewnętrznego, dlatego będzie on tu rozumiany jako „zróżnicowanie poglądów, tematów, opinii, idei i stanowisk oraz ich reprezentacji politycznej i kulturowej w ramach danego systemu medialnego”, a nie jak wcześniej „w tej samej gazecie, czasopiśmie, a także kanale radia i telewizji”.

$5 \quad$ Warto zaznaczyć, że w niniejszym tekście odrzucone zostaje dość powszechne rozumienie pluralizmu medialnego w kategoriach „zerojedynkowych”, polegające na stwierdzeniu, że albo on jest, albo go nie ma, bez namysłu nad jego jakością. Przeciwnie - jakość ta jest tutaj kategorią centralną, a pytania o nią poddawane są pod rozwagę. 


\section{Media na rynku}

Zanim przejdziemy do omawiania spraw stricte związanych z pluralizmem medialnym, zastanówmy się nad uwarunkowaniami, jakie dotyczą podmiotów komunikowania masowego w ogóle. Po 1989 roku nastał w Polsce czas „wolnego rynku”, także w świecie mediów. Mimo że jawi się on dziś powszechnie jako jedyne rozsądne rozwiązanie, to nie sposób nie zauważyć płynących z tego konsekwencji. Są nimi, po pierwsze, bariery. Bariery rozumiane dwojako, zarówno jako ograniczenie dla odbiorców, jak i dla wytwórców mediów. Odbiorcy tylko w teorii mają powszechny dostęp do wszystkich środków masowego przekazu, bowiem nie na wszystkie tytuły ich po prostu stać. Niektóre pisma są wprost określane jako ekskluzywne, czyli z zasady ograniczające dostęp do nich dla lepiej sytuowanych. Podobnie jest z telewizją. Mniejszy to jednak problem w porównaniu do problemów (potencjalnych) wytwórców mediów, którzy chcieliby stworzyć swój środek komunikowania masowego. Ma rację Piotr Żuk pisząc, że „stwierdzenie, iż każdy może założyć własną gazetę i głosić co mu się podoba jest skrajną naiwnością socjologiczną. Początkowe nakłady finansowe, ilość środków [...] koniecznych obecnie do uruchomienia nowego tytułu prasowego (nawet na poziomie lokalnym) - a tym bardziej stacji telewizyjnej - stanowi wystarczającą barierę"6. Według Beaty Klimkiewicz wysokość inwestycji, jaka była potrzebna w 2004 roku, aby wprowadzić na polski rynek dziennik ogólnokrajowy, wynosiła $100 \mathrm{mln}$ złotych, która to kwota była dwunastokrotnie mniejsza niż w przypadku uruchomienia ogólnokrajowej telewizji prywatnej ${ }^{7}$ W 2006 roku Axel Springer przeznaczył na samą tylko promocję „Dziennika” $75 \mathrm{mln}$ złotych ${ }^{8}$.

Media niewątpliwie są uzależnione od pieniędzy, gdyż nawet jeśli powyższe bariery uda się pokonać, to tylko za pomocą jakiejś formy kredytu, który w przyszłości trzeba będzie spłacić. To prowadzi nas nieuchronnie do stwierdzenia, że o „być albo nie być” mediów na rynku decyduje poziom oglądalności (telewizja), sprzedaży i czytelnictwa (czasopisma), słuchalności (radio), itp. Mamy zatem presję ekonomiczną, o której Piotr Żuk pisze: „Uniemożliwia [ona] prezentowanie wielu poglądów. Niekomercyjne poglądy na życie i świat, mniejszościowe (kulturowo, politycznie, społecznie) opi-

$6 \quad$ P. Żuk, Media a kontrola społeczna w czasach „wolności rynkowej”, w: Media i władza: demokracja, wolność przekazu i publiczna debata w warunkach globalizacji mediów, red. P. Żuk, Warszawa 2006, s. 44.

7 Zob. B. Klimkiewicz, Własność medialna i jej wpływ na pluralizm oraz niezależność mediów, Kraków 2005, s. 85.

8 Zob. T. Mielczarek, Monopol, pluralizm, koncentracja. Środki komunikowania masowego w Polsce w latach 1989-2006, Warszawa 2007, s. 101. 
nie, oferty kulturowe nieschlebiające masowej publiczności mają niewielką albo wręcz żadną możliwość zaistnienia w mediach zamkniętych w rynkowej klatce”. Owa „rynkowa klatka” znacznie ogranicza możliwości czasowe, chociażby, informacji (newsów) podawanych przez media. Także ich forma powinna być skonstruowana tak, aby przykuwać uwagę, najlepiej, jeśli jest sensacyjna, dramatyczna lub co najmniej efektowna. W pośredni sposób wyjaśnia to, zaobserwowane ostatnio zjawisko „palikotyczności” mediów, czyli „wdzierania" się doń ludzi, którzy w sposób kontrowersyjny, a nawet szokujący przedstawiają (promują) swoje poglądy i samych siebie. Następnie, na owe osoby automatycznie kierowana jest uwaga mediów, niezależnie od tego, czy ich działania są tego warte.

Powyższe rozważanie prowadzi nas w stronę koncepcji agenda-setting, na rozwinięcie której nie ma tutaj miejsca. Warto jedynie wspomnieć, że według niej media ustalają hierarchę wydarzeń, o których informują publiczność, przez co „wyznaczają odbiorcom tematy do rozmów, decydują, o jakich sprawach ludzie myślą i dyskutują"10. Stosując niezbędne uproszczenie, należy w tym miejscu przejść do stwierdzenia, że media (współ)tworzą w ten sposób zjawisko mainstreamu społeczno-kulturowego, w którym funkcjonuje większość społeczeństwa, do którego przekaz jest skierowany. Większość ta następnie myśli i postrzega rzeczywistość za pomocą kategorii wytworzonych przez ów główny nurt. Żuk pisze, że „odbiegające od głównego nurtu społeczno-politycznego propozycje (nie) są w ogóle nieobecne w mediach. Pojawiają się tam, ale w ściśle określonej roli - jako barwna ciekawostka, [...] dziwactwo, folklor polityczny, obyczajowy, środowiskowy"11. W kategoriach socjologicznych możemy mówić o zjawisku trwałej stygmatyzacji danych jednostek/grup/środowisk poprzez nadawanie im określonych „łatek” (np. tzw. „obciachu”, „oszołomstwa”, itp.)

Szersze rozważania na temat mainstreamu i mediów go tworzących/podtrzymujących niestety również wykraczają poza ramy niniejszej pracy. Są one jednak immanentnie związane z pojęciem pluralizmu, w takim rozumieniu jak zostało to wcześniej określone. Wydaje się bowiem, że bez analizy mainstreamu właśnie, jego trwałości, szerokości, odporności na zmiany nie da się odpowiedzieć na pytania związane z jakością pluralizmu. Cóż bowiem z tego, że na rynku dostępnych jest wiele tytułów, czy to prasowych, telewizyjnych czy radiowych, jeśli bardzo niewiele z nich (lub np. jedno) bierze realny udział w tworzeniu głównego nurtu społeczno-kulturowego?

\footnotetext{
P. Żuk, dz. cyt., s. 44.

Agenda-setting, w: Stownik..., s. 4.

P. Żuk, dz. cyt., s. 45-46.
} 
Jeszcze jeden wątek nie może pozostać tutaj bez zasygnalizowania: reklamy. To one, bowiem są dzisiaj nieodzownym składnikiem przekazu mediów masowych. „Układanie programów zgodnie z żądaniami hojnych reklamodawców jest standardem w prywatnych stacjach telewizyjnych. Godziny największej oglądalności mają być wypełnione ofertą, która przyciągnie przed telewizor jak najliczniejszą publiczność. [...] Kontrowersyjne i oryginalne opinie nie mogą być emitowane w porze największej oglądalności - jest to zbyt ryzykowne dla interesów reklamodawcy. [...] Również na rynku prasowym uzależnienie od stałych nabywców reklam jest ogromne"12. Powyższe spostrzeżenia uzmysławiają nam podstawowe zagrożenie dla pluralizmu w mediach: w najlepszym czasie antenowym (w najlepszym usytuowaniu, jeśli chodzi o prasę) nie mogą znaleźć się poglądy niepopularne. To reklamodawcy zatem, w pewnym sensie, cenzurują treści przekazywane w mass mediach. $80 \%$ przychodów zarówno prasy, jak i telewizji pochodzi od nich właśnie ${ }^{13}$, w związku z czym ich zdanie jest nie do zbagatelizowania. Ponadto, coraz częściej trudno jest oddzielić reklamy od artykułów prasowych bądź programów telewizyjnych - mamy dość powszechnie do czynienia ze zjawiskiem kryptoreklamy. Firma umieszczając daną reklamę w gazecie oczekuje, że pojawi się tekst redakcyjny wspomagający ową kampanię ${ }^{14}$.

Biorąc powyższe rozważania pod uwagę, dochodzimy do przekonania, że obserwujemy coś, co można by nazwać swoistą „cenzurą rynku”. Wolny rynek, który w dziedzinie mediów jawił się jako ich wyzwoliciel z „totalitarnych okowów" i monopolu informacyjnego doprowadził do innego rodzaju monopolu - monopolu rynku, który „z punktu widzenia interesów odbiorcy informacji [...] niczym nie różni się od monopolu państwa"15. Jest jednak dużo skuteczniejszy, gdyż nie jawi się jako zagrożenie, usypiając czujność odbiorców mediów.

\section{Prawne ramy mediów w Polsce}

Mając na uwadze powyższe rozważania, czas przejść do zgłębienia polskiej rzeczywistości medialnej po 1989 roku. Po demonopolizacji rynku medialnego, likwidacji instytucji cenzury i Robotniczej Spółdzielni Wydawniczej Prasa-Książka-Ruch oraz w wyniku innych konsekwencji transformacji politycznej i ekonomicznej wyłoniły się dwie strategie (wizje) działania na tym polu: wobec prasy zastosowano nadzorowaną prywatyzację i politykę

12 Tamże, s. 48.

13 B. Nierenberg, Między rynkiem a wolnościa dziennikarska, w: Media a demokracja, red. W. Mich, L. Pokrzycka, Lublin 2008, s. 157.

14 Tamże, s. 158.

15 P. Żuk, dz. cyt., s. 56. 
deregulacyjną, natomiast wobec radiofonii i telewizji, zależnej od kontroli regulacyjnej państwa, zastosowano duopol własności prywatnej i publicznej. „Taka mozaika własności medialnej w Polsce podlegała dalszym modyfikacjom, ale też wyzwaniom szybkiego rozwoju ekspansji monomedialnej, krzyżowej koncentracji medialnej, regionalnej konsolidacji, synergicznych inwestycji oraz komercjalizacji nadawców publicznych, przede wszystkim pod względem sposobu ich finansowania [...], a także roli programowej"16. Ramy prawne (obok przepisów konstytucyjnych) zostały wyznaczone przez trzy ustawy: Prawo Prasowe z 1984 roku, Ustawę o Krajowej Radzie Radiofonii i Telewizji z 1992 roku, oraz Ustawę o Ochronie Konkurencji i Konsumentów z 2000 roku (ta ostatnia, rzecz jasna, nie odnosi się tylko do mediów, ale reguluje kwestie związane z ich koncentracją, co jest istotne z punktu widzenia niniejszych rozważań). Instytucją powołaną do regulacji (przyznawania i odbierania częstotliwości, koncesji) telewizji i radia oraz czuwania nad przestrzeganiem przez ich podmioty zasad ustawowych została Krajowa Rada Radiofonii i Telewizji. Gazety z kolei, niemal całkowicie uwolnione zostały od jakiejkolwiek kontroli ze strony instytucji państwowych, choć chętnie korzystały np. $z$ ulg podatkowych i innych form dotacji pośrednich lub bezpośrednich.

Według ustawy o radiofonii i telewizji (przypomnijmy: sprawującej pieczę tylko nad radiem i TV) „koncesji nie udziela się w sytuacji, gdy rozpowszechnianie programów przez wnioskodawcę mogłoby spowodować osiągnięcie przez niego pozycji dominującej w dziedzinie środków masowego przekazu na danym terenie" ${ }^{17}$. Ustawa ta nie definiuje jednak pojęcia „pozycja dominująca". Termin ten znalazł się dopiero w ustawie z 2000 roku, gdzie określa się, że udział w rynku danego podmiotu nie może przekroczyć $40 \%$.

W tym miejscu należy przywołać dość istotne rozróżnienie, które wymyka się zupełnie prawnym regulacjom. Są trzy rodzaje koncentracji mediów:

1) diagonalna („krzyżowa” integracja własności i kapitału w ramach różnych sektorów medialnych );

2) wertykalna (występuje w obrębie różnych etapów produkcji i dystrybucji medialnej);

3) horyzontalna (występuje w ramach jednego sektora medialnego) ${ }^{18}$.

16 B. Klimkiewicz, dz. cyt., s. 50.

17 Tamże, s. 51.

18 Zob.: tamże, s. 52; Słownik terminologii medialnej, dz. cyt., w haśle „koncentracja (własności) mediów" przypisuje nieco inne znaczenia wertykalnej i diagonalnej koncentracji, moim zdaniem mniej trafne. 
Właśnie ten ostatni rodzaj koncentracji jako jedyny jest przedmiotem zainteresowania przepisów antykoncentracyjnych. Koncentracja diagonalna była przedmiotem prac nad nowelizacją ustawy medialnej w 2002 roku, jednak powszechnie znane okoliczności, do jakich doszło podczas jej tworzenia (afera Rywina) spowodowały, że zmiany w tym zakresie się nie dokonały. W związku z tym nie ma w tej chwili ograniczeń integracji własności i kapitału w ramach różnych sektorów medialnych. Jedyne ograniczenie stanowi zapis mówiący o konieczności zgłoszenia zamiaru koncentracji, jeśli biorące w niej udział podmioty gospodarcze przekroczą granicę obrotu $50 \mathrm{mln}$ euro (ustawa o ochronie konkurencji i konsumentów). Warto zwrócić uwagę, że powyższe, niewystarczające jak się wydaje, ograniczenia dotyczą jedynie zewnętrznego aspektu pluralizmu, nie poruszając w ogóle jego aspektu wewnętrznego.

Warto przywołać jeszcze jedno rozróżnienie, jeśli chodzi o zmiany własnościowe podtrzymujące tendencje monopolistyczne na rynku prasowym. Wyróżnić można bowiem takie działania podmiotu gromadzącego w swych rękach wiele tytułów, jak:

« Tematyczna specjalizacja - rozszerzenie dotychczasowej oferty o tytuły nowe, ale należące do tej samej specjalizacji (przykład: działalność Wydawnictwa H. Bauer w Polsce);

๙ Dywersyfikacja - wprowadzenie nowych lub przejęcie istniejących tytułów z nowych segmentów rynku (tę strategię konsekwentnie stosuje Agora);

๙ Regionalna konsolidacja - przejmowanie tytułów na rynku regionalnym i ujednolicanie różnych form działalności prasowej i reklamowej z tym związanych (na przykład działalność Polskapresse) ${ }^{19}$.

Wspomniana wcześniej afera Rywina, wzbudzająca swego czasu wiele emocji, słusznie uważana jest za przełom $\mathrm{w}$ funkcjonowaniu rynku medialnego w Polsce. Żeby jednak odpowiedzieć na pytanie, dlaczego tak się stało, należy prześledzić funkcjonowanie głównego aktora w przestrzeni medialnej Polski po 1989 roku.

\section{Pozycja „Gazety Wyborczej”}

$\mathrm{Na}$ rynku dzienników prasowych niepodzielną rolę lidera według wszystkich istotnych wskaźników przez zdecydowanie najdłuższy okres pełniła „Gazeta Wyborcza”. Pierwszy numer ukazał się 8 maja 1989 jeszcze jako wynik negocjacji „okrągłostołowych" ${ }^{20}$. Wydawcą gazety była i jest spółka

Zob. tamże, s. 64.

20 W praktyce była to indywidualna decyzja Lecha Wałęsy. 
założona przez Zbigniewa Bujaka, Andrzeja Wajdę i Aleksandra Paszyńskiego - Agora S.A. Aż do pojawienia się „Faktu”, GW nie miała sobie równych, jeśli chodzi o sprzedaż. Najbliżej niej był dziennik o charakterze bulwarówki „Super Express”. „Rzeczpospolita” - drugi, obok „Wyborczej”, dziennik o charakterze opiniotwórczym - oscylował początkowo na poziomie $50-60 \%$ sprzedaży swojego największego konkurenta (GW), by z czasem spaść zdecydowanie poniżej poziomu połowy sprzedaży głównego dziennika w Polsce.

Średnia sprzedaż „Wyborczej” do 2003 roku (rozkwit afery Rywina, pojawienie się „Faktu”) wahała się między 392 tys. (1995 rok) a 458 tys. (2001 rok) egzemplarzy. W kwietniu 2006 roku na rynku pojawił się trzeci istotny opiniotwórczy dziennik - „Dziennik. Polska. Europa. Świat”. Mimo początkowego optymizmu, związanego z wysoką sprzedażą, wydawcy musieli się pogodzić z tym, że wkrótce rozpoczęła się tendencja spadkowa. Co ciekawe, po pojawieniu się „Faktu”, którego sprzedaż waha się między 437 tys. (2003 rok) a 535 tys. (2004 rok), „Gazecie Wyborczej” sprzedaż wcale nie spadła, a utrzymywała się na podobnym poziomie. Potwierdza to tezę, że pojawienie się tego tabloidu nie okazało się konkurencją dla GW, a raczej dla gazet lokalnych i „Super Expressu”, któremu sprzedaż wyraźnie spadła (z 273 tys. w 2003 do 198 tys. w 2007 roku ${ }^{21}$.

Interesująco przedstawiają się dane dotyczące wpływów z reklam dzienników ogólnopolskich jeszcze sprzed przełomu z 2003 roku. W 2001 roku „Gazeta Wyborcza”, zdecydowany lider tej klasyfikacji, zarobiła $450 \mathrm{mln}$ złotych. Na drugim miejscu znalazła się „Rzeczpospolita” - 133 mln. Rok później „Wyborcza” zwiększyła zysk aż do $717 \mathrm{mln}$ złotych, podczas gdy ponownie druga „Rz” zmniejszyła wpływy do $122 \mathrm{mln}^{22}$.

Można by przytaczać wiele liczb potwierdzających zdecydowaną pozycję „Gazety Wyborczej” na rynku prasowych dzienników ogólnopolskich, zwłaszcza w pierwszej dekadzie po 1989 roku. Skupmy się jednak raczej na kilku zdarzeniach, które pokazują potencjalne i realne konsekwencje tej przewagi. W kwietniu 1999 roku Agora weszła na giełdę papierów wartościowych. Doszło wówczas do kontrowersyjnego uwłaszczenia 1530 pracowników agory (powołano Agora Holding kontrolowaną przez Helenę Łuczywo, Wandę Rapaczyński, Piotra Niemczyckiego, Seweryna Blumsztajna, Ernesta Skalskiego i Juliusza Rawicza, których akcje warte były około miliard złotych $)^{23}$.

${ }^{21} \quad$ Wszystkie dane odnośnie do sprzedaży pochodzą ze strony Związku Kontroli Dystrybucji Prasy [www.zkdp.pl; dostęp: 21.02.2009].

22 Na podstawie: Media w Badaniach, red. M. Polewska, Poznań 2003, s. 13

23 Zob. T. Mielczarek, dz. cyt., s. 97. 
Czy taka ogromna przewaga jednego podmiotu nad innymi jest korzystna dla jakości pluralizmu? Pytanie nabiera dodatkowego wymiaru, gdy przytoczymy słowa Tomasza Mielczarka: „ujmując rzecz w jak największym uproszczeniu, można stwierdzić, że Agora i wydawany przez nią dziennik zmieniały się ze środowiska bieżącej walki politycznej i ideowej polemiki w medialny koncern, w którym coraz większe znaczenie zyskiwały parametry ekonomiczne"24. Posiadanie własnych wyraźnych poglądów, o których z dumą mówił Piotr Pacewicz ${ }^{25}$, to nic złego, jednak w przypadku tak potężnego medium ma to swoje niezaprzeczalne konsekwencje. Dla nas najistotniejsza wydaje się kwestia wpływu takiego stanu rzeczy na „różnorodność oferty środków komunikowania masowego, rozmaitość programową, odnoszącą się do zróżnicowanych systemów wartości, zapewnienie wielostronnej politycznie informacji, a także zapobieganie tendencjom monopolistycznym" (definicja pluralizmu). Czy nie ma tu miejsca zawężanie mainstreamu, idei, które mogą się realnie przedostać do głównego nurtu społeczeństwa? Spójrzmy na przypuszczalne konsekwencje takiego stanu rzeczy. Jeśli przyjmiemy, że linia „Gazety Wyborczej” od początku jej istnienia była wyraźnie antylustracyjna i nie przejawiała radykalnego antykomunizmu (jest to założenie, którego przyjęcie nie wiąże się z dużym ryzykiem pomyłki), to jakże ciekawego wymiaru nabiera stwierdzenie autorstwa Walerego Pisarka: „W latach 1989-1992 w każdym z tych 11 miast [chodzi o główne polskie miasta - przyp. F. G.] powstała co najmniej jedna całkowicie nowa gazeta codzienna. $Z$ reguły reprezentowała ona stanowisko radykalnie antykomunistyczne w ogóle, a antysowieckie w szczególności, prolustracyjne i prorynkowe. Gazety tego typu po kilku latach, a czasem już po kilku miesiącach albo zniknęły z rynku prasowego, albo znacznie ograniczyły wojowniczość swojej publicystyki"26.

Nie ma oczywiście bezpośrednich przesłanek wskazujących na związek przyczynowo-skutkowy między zawężeniem idei i poglądów mainstreamu przez posiadające dominującą pozycję medium (w tym przypadku $\mathrm{GW}$ ), a opisanym przez Pisarka wydarzeniem (i zapewne setkami innych, podobnych wydarzeń na różnych płaszczyznach). Wykluczyć go jednak nie można.

Należy pamiętać, że moc oddziaływania „Gazety Wyborczej” nie ograniczała się jedynie do pisania tekstów na swoich łamach. Teksty te były przecież po wielokroć cytowane przez inne media oraz wyznaczały im pole zainteresowania (por. koncepcja agenda-setting), a ludzie związani z tym tytułem,

Tamże, s. 96.

Zob. tamże, s. 92.

W. Pisarek, Zmiany oferty na rynku prasy codziennej, w: Media $i$ dziennikarstwo $w$ Polsce 19891995, red. G. G. Kopper, I. Rutkiewicz, K. Schliep, Kraków 1996, s. 48. 
postrzegani jako elita dziennikarstwa w Polsce i środowisko obdarzone wysokim prestiżem, posiadali możliwość wyznaczania trendów w sferze symbolicznej. GW była podstawowym „medium pierwotnym”, którego ustalenia oddziaływały w największym stopniu na "media wtórne” (głównie telewizję), a to najlepiej świadczy o sile jej „impaktu” na całe społeczeństwo. Brak poważnych alternatyw sprawił, że próba negatywnego (bądź pozytywnego) zestygmatyzowania danego środowiska za jej pomocą, miała bardzo dużą szansę powodzenia (niezależnie od stanu faktycznego - w sensie faktów społecznych Emila Durkheima).

Jest jeszcze zewnętrzny aspekt pluralizmu medialnego, który także dotyczy Agory. Zdaniem Beaty Klimkiewicz zmiany własnościowe o charakterze dywersyfikacji (oznaczającej wprowadzenie nowych lub przejęcie istniejących tytułów z nowych segmentów rynku) ,są praktykowane w najbardziej widoczny sposób przez Agorę, która stopniowo wkracza w różne dziedziny aktywności medialnej" ${ }^{27}$. Chodzi zapewne między innymi o działania dążące do monopolu na rynku radiowym, za które Agora została zresztą upomniana w jednym z raportów KRRiT razem z Holdingiem $\mathrm{ZPR}^{28}$. To zaś działanie jest niczym innym jak dążeniem do, wspomnianej wcześniej, diagonalnej (krzyżowej) koncentracji mediów. Klimkiewicz w innym miejscu pisze, że zdaniem Parlamentu Europejskiego, Komitetu Ekonomiczno-Społecznego i różnych organizacji dziennikarskich „istnieje ryzyko zagrożenia pluralizmu mediów przede wszystkim za sprawą koncentracji mediów i własności krzyżowej podmiotów medialnych"29. Pamiętajmy też o tym, że gdyby nie afera Rywina, Agora zapewne kupiłaby Telewizję Polsat.

\section{Między totalitaryzmem a pluralizmem}

Określenie pozycji „Gazety Wyborczej” w latach 90. XX wieku mianem monopolisty wydaje się niewystarczające. Z pewnością można stwierdzić, że przed 1989 rokiem mieliśmy na rynku medialnym do czynienia z totalitaryzmem, związanym z centralistyczną rolą państwa, cenzurą, etc. Po Okrągłym Stole i pojawieniu się „Gazety Wyborczej” przeszliśmy najprawdopodobniej

27 B. Klimkiewicz, dz. cyt., s. 64.

28 Zob. tamże, s. 71-72; o innych działaniach Agory mających na celu koncentrację „krzyżową" własności na rynku medialnym patrz: s. 73.

29 Tamże, Zderzenie standardów racjonalności? Pluralizm mediów w europejskiej polityce medialnej, w: Global Media Journal-Polish Edition 2006, nr 1, s. 6. Wersja PDF dostępna w Internecie: [http://www.globalmediajournal.collegium.edu.pl/artykuly/wiosna\%202006/KlimkiewiczPluralizm\%20mediow\%20w\%20europejskiej\%20polityce\%20media.pdf; dostęp: 09.03.2009]. 
od owego totalitaryzmu do stanu HEGEMONICZNościo ${ }^{30}$ jednego medium, który to stan trwał ponad 10 lat. Zauważmy, iż w tym czasie na polu kulturowym wśród członków społeczeństwa zapewne zdążyły się już zakorzenić pewne postawy i wzory postępowań. Brak realnych alternatyw sprawił, że w zasadzie nie doszła do skutku wspomniana wcześniej „powszechna debata w dyskursie publicznym, odbywająca się na zasadach pluralizmu", podczas której różne środowiska, reprezentujące czasem inne niż główny nurt społeczno-polityczny systemy wartości, wzięłyby udział w podziale władzy i kształtowaniu nowego państwa. Przykładowo, środowiska kwestionujące zasadność wszechobecności wolnego rynku, niezwolennicy liberalizmu, obawiający się prywatyzacji, nieentuzjaści kultury masowej, żarliwi katolicy, zwolennicy twardego rozliczenia z poprzednim systemem i wiele innych środowisk zostali zwyczajnie wykluczeni poza nawias dominującego dyskursu publicznego. Niektórych zestygmatyzowano, nadając im łatki „oszołomów”, „prawicowców”, „chorych z nienawiści”, etc.; a niektórych po prostu ignorowano do tego stopnia, że niezorientowany „posłuszny” mainstreamowi odbiorca mógł nawet nie dowiedzieć się o ich istnieniu.

Należy w tym miejscu dokonać stosownego doprecyzowania. Zamysłem autora nie jest rozstrzyganie tego, które z ideologii, podejść czy stanowisk jest bądź było słuszne czy też potrzebne. Tak wiele segmentów życia społecznego podczas transformacji wymagało i wciąż wymaga zmian, że trudno sobie wyobrazić, aby jedno tylko podejście, jako takie, było słuszne. Nie jest to jednak w ogóle w tym miejscu istotne. Kwestią kluczową jest niedopuszczenie środowisk, które miały odmienne poglądy niż środowisko związane z "Gazetą Wyborczą”, do realnego zabrania głosu. Nie użyto wprawdzie przemocy fizycznej wobec „niepokornych środowisk”, ale użyto najprawdopodobniej przemocy symbolicznej. Pojęcie to wprowadził do socjologii Pierre Bourdieu i do dziś jest jego klasykiem ${ }^{31}$. Jest ona tyle groźniejsza od jej fizycznej odpowiedniczki, że niemal niewidzialna i nieprzenikniona, przez co nie wzbudza podejrzeń. W czasach totalitaryzmu PRL-u większość ludzi wiedziała, że mediom nie można ufać, że treści w nich zawarte to kłamstwa i propaganda, i że należy się przeciwko nim buntować. Teraz, gdy na co dzień słyszą, że media są wolne i niezależne, ich czujność jest uśpiona.

W 2002 roku Adam Michnik nagrał Lwa Rywina, który przyszedł do niego z propozycją korupcyjną i to, jak się później okazało, było zwrotnym

30 Adam Michnik w wywiadzie dla „Przekroju”, stwierdził niedawno, że „«Gazeta Wyborcza» dalej jest hegemonem debaty na tematy ważne” („Przekrój”, 21 IV 2009, „Michnik: Truchło IV RP jest wśród nas i cuchnie").

31 Zob. P. Bourdieu, Language \& symbolic power, Cambridge 1995. 
punktem dla ładu medialnego III RP. Wprawdzie w ciągu pięciomiesięcznego „śledztwa” dziennikarskiego pojawiały się plotki o tym zdarzeniu ${ }^{32}$, jednak na dobre Rywingate nabrała tempa dopiero w 2003 roku. Zagraniczni inwestorzy (m.in. Axel Springer) zaczęli dostrzegać wyłaniającą się w owym ładzie medialnym przestrzeń do zagospodarowania, w której, dzięki agresywnej kampanii promocyjnej, zdołali umieścić znaczący tytuł. Co jednak ważniejsze, zniknęły niektóre tematy tabu ${ }^{33}$, a przestrzeń dyskursu się poszerzyła.

Za pomocą zarysowanego powyżej modelu: totalitaryzmhegemoniczność-pluralizm można jak się wydaje dość wiernie oddać rzeczywistość ładu medialnego w III RP. Pamiętajmy jednak, że pozycja „Gazety Wyborczej"/Agory wcale znacząco nie spadła, tymczasem trzeci liczący się (obok „Rzeczpospolitej” i GW właśnie) opiniotwórczy, ogólnopolski dziennik prasowy - „Dziennik” - po znakomitej sprzedaży na początku, wciąż odnotowuje tendencję spadkową. Czy przewaga zasobów, jaką przez ponad dekadę wypracowała „Gazeta Wyborcza”, i fakt głębokiego zakorzenienia w społeczeństwie idei przez nią promowanych pozwoli na funkcjonowanie prawdziwego pluralizmu medialnego o wysokiej jakości? „Fakt”, jedyna gazeta mogąca walczyć z GW o pozycję lidera sprzedaży, nie jest dziennikiem opiniotwórczym, lecz tabloidem. Jej wpływ na rzeczywiste kształtowanie/podtrzymywanie jakiejś idei, postaw czy wzorów zachowań jest znacznie mniejszy właśnie ze względu na ową formę, jaką ta gazeta przybrała (tej formie też zawdzięcza zapewne tak wysoką sprzedaż).

Osobnym problemem jest fakt, że z omawianych tu tytułów „Gazeta Wyborcza” właśnie jako jedyna ma polskiego wydawcę! Pozostałe gazety są wydawane przez spółki, których pakiety większościowe są w posiadaniu zagranicznych właścicieli. Czy to wpływa na linię gazety? Sondaż przeprowadzony przez Zbigniewa Bajkę w 2000 roku wśród dziennikarzy, poruszył problem ich (dziennikarzy) swobody podczas wykonywania zawodu. Na pytanie: „Kto lub co ogranicza wolność dziennikarską?" 42\% odpowiedziało, że jest ona ograniczana przez „naciski właścicieli, szefów redakcji, stacji, bezpośrednich przełożonych" ${ }^{34}$.

32 W wywiadzie przeprowadzonym przez Janinę Paradowską („Polityka”) w 2002 z ówczesnym premierem L. Millerem znalazł się fragment dotyczący owej sprawy. Po przesłaniu tekstu do autoryzacji A. Michnik, dowiedziawszy się o tym, poprosił o usunięcie kontrowersyjnej części wywiadu, co autorka uczyniła.

33 Zob. np. pojawienie się na antenie TVN-u (medium dotychczas uważanego za sojusznika GW) w 2008 roku filmu „Trzech Kumpli”, w którym obnażone zostało funkcjonowanie gazety.

34 Cyt za: B. Klimkiewicz, Własność medialna..., s. 88. 


\section{RP}

\section{Jałowy pluralizm?}

Czy powyższe fakty nie burzą nadziei, że w Polsce po 2003 roku mamy wreszcie do czynienia z wysoką jakością pluralizmu medialnego? Z całą pewnością stawiają je pod dużym znakiem zapytania. W tym miejscu nasuwa się koncepcja "jałowego pluralizmu" (feckless pluralism) zasygnalizowana przez Thomasa Carothersa w 2002 roku $^{35}$. Znakomity badacz procesów demokratycznych używał tego pojęcia między innymi do sytuacji, w której demokracja pozostaje płytka (shallow), a obywatele skłaniają się do bycia niezadowolonymi z polityki i są odcięci od politycznego uczestnictwa poza głosowaniem w wyborach. ${ }^{36} \mathrm{~W}$ Polsce - mimo że frekwencja wyborcza należy do najniższych w Europie, narzekanie na politykę i polityków słyszy się powszechnie, a poziom wielu instytucji publicznych jest głęboko niezadowalający (np. sądownictwa) - wydaje się, że demokracja (choć często fasadowa) nie jest płytka. Świadczą o tym przede wszystkim rozwijające się instytucje $\mathrm{z}$ trzeciego sektora (non-profit), których wpływ na rzeczywistość wydaje się być coraz większy.

Pełnej odpowiedzi na pytanie o jakość polskiej demokracji jako całości można by jednak udzielić dopiero po szczegółowym przeanalizowaniu przebiegu transformacji na dwóch pozostałych polach, zarysowanych we wstępie pracy: prawnym i instytucjonalnym. W niniejszym tekście podjęta została próba zmierzenia się z odpowiedzią na pytanie o jakość pluralizmu medialnego po 1989 roku w Polsce, przy założeniu, że odgrywa on niebagatelną rolę na polu przemian kulturowych. Bez wysokiej jakości pluralizmu medialnego projekt polityczny III RP będzie zawsze obarczony grzechem „nieprawomocnego wykluczania". W modelu normatywnym bowiem, wykluczanie poza nawias dominującego dyskursu publicznego jest prawomocne, ale jedynie wobec środowisk o skrajnie radykalnych postawach, niezależnie od prezentowanej opcji (np. faszyści, anarchiści czy komuniści), nie zaś wobec środowisk o poglądach nie-skrajnych (a po prostu określonych), niezgodnych z poglądami środowisk dominujących.

F I L I P G O Ł E B I E W S K I

35 Zob. T. Carothers, The end of the transition paradigm, w: "Journal of Democracy” 2002, nr 1 (13), s. 10-16. PDF dostępny na stronie internetowej: [http://www.journalofdemocracy. org/articles/gratis/Carothers-13-1.pdf; dostęp: 09.03.2009].

36 Zob. tamże, s. 10-12. 


\section{Abstract}

This article distinguishes three key fields in which transformation in Poland should perform: a legislative, an institutional and a cultural one. The main part of the reasoning is focused on the last one. It is claimed that mass media are the most influential factors that create (or disperse) such phenomena as: national identity, historical remembrance, citizenship, intension to serious debate, subjectivity consciousness. These phenomena are connected with such things as: patterns, norms and values that lay upon the cultural field of the transformation. Thanks to them, members of the society can find themselves again after years of subordination to PRL. That's why it is so important for the society to have fully-pluralistic media.

The next part of this article shows the conditions resulted from media's existence on a free market. Ubiquity of advertisements, financial barriers for both producers and receivers of media and compulsion of attractiveness of media transmission cause a specific "market censorship" that remains unnoticed by the society. Naxt, the law frames of media functioning in Poland are presented. It is shown that newspapers in comparison to TV or radio had much more discretion, especially in first ten years of transformation.

The next part of the article is devoted to the main mass media in Poland "Gazeta Wyborcza". Many indicators show that the position of this newspaper was totally dominant and it negatively affected the quality of pluralism in media. For the first ten years, there was no real alternative for Agora's newspaper and during this time it gained meaningful advantage of resources (especially financial ones) over the rest of Polish newspapers. All the observations led to a cognitive model according to which media state before 1989 can be called "totalitarian", state between 1989-2003 can be called "hegemonic" referring to "Wyborcza" position. From 2003 (year of Rywingate and Axel Springer's encroachment to Polish media market) we can believe that pluralism appeared in the field of mass media. Although, there are still doubts that present media state can only be called a feckless pluralism (Thomas Carother's notion). 